\title{
PEMANFAATAN MEDIA SOSIAL DAN MARKETPLACE UNTUK PENJUALAN PRODUK UMKM
}

\author{
Wasino $^{1}$ \\ ${ }^{1}$ Program Studi Sistem Informasi, Universitas Tarumanagara \\ email:wasino@fti.untar.ac.id
}

\begin{abstract}
UMKM is a business that someone, group, or company has already fulfill the terms or conditions as micro business. Base on the Jambi news site which can be accessed on February, $1^{\text {st }} 2021$ represent the amount of UMKM that located in Jambi City in 2020 is 3.513 UMKM. The main problem that exists in UMKM is classic namely funding. Besides that, the other problems is about UMKM products marketing and sales, and how to distribute them to reach wider. In total of 92 UMKM owner in Jambi were given seminars, socialization, and training that the use of social media and marketplace are important to support promotion, marketing and UMKM products distribution. Based on the discussion with owners of UMKM, known that UMKM owners are interested to take advantage of marketplace and online store to promote their UMKM products, however the facilities development for online stores not yet possible for them because they do not have the resources to support the online store. There is one UMKM owner who has made good use of e-commerce, namely through the use of business Instagram and Facebook and use of marketplaces. UMKM owners need assistance in electronic commerce and need support for a stable internet network in their area.
\end{abstract}

Keywords: UMKM, Social Media, Marketplace, Online Store

ABSTRAK
Usaha Mikro, Kecil, dan Menengah yang disingkat menjadi UMKM merupakan usaha yang dimiliki oleh perorangan, kelompok, maupun badan usaha yang telah memenuhi syarat atau ketentuan sebagai usaha mikro. Berdasarkan pada situs berita Jambi yang diakses pada tanggal 01 Februari 2021 menunjukkan bahwa jumlah UMKM yang ada di kota Jambi pada tahun 2020 sebanyak 3.513 UMKM. Masalah utama yang dihadapi pelaku UMKM adalah klasik yaitu pendanaan. Selain itu masalah yang dihadapi adalah mengenai pemasaran dan penjualan produk UMKM dan cara pendistribusiannya untuk menjangkau yang lebih luas. Sebanyak 92 pelaku UMKM di Jambi diberikan seminar, sosialisasi dan pelatihan bahwa penggunaan media sosial dan marketplace sangat penting dalam mendukung promosi, pemasaran dan pendistribusian produk UMKMnya. Berdasarkan pada pembahasan bersama dengan para pelaku UMKM, diketahui bahwa para pelaku UMKM sangat tertarik dalam memanfaatkan marketplace dan online store untuk memasarkan produk UMKMnya, namun demikian pembangunan fasilitas untuk online store belum memungkinkan bagi mereka karena sumberdaya yang belum dimiliki untuk mendukung online store. Terdapar salah satu pelaku UMKM yang telah memanfaatkan ecommerce dengan baik yaitu melalui penggunaan instagram dan facebook bisnis serta marketplace. Para pelaku UMKM memerlukan pendampingan dalam melakukan perdagangan secara elektronik dan perlu dukungan jaringan internet yang stabil di daerahnya.

Kata kunci: UMKM, Media Sosial, Marketplace, Online Store.

\section{PENDAHULUAN}

\section{Analisis situasi}

UMKM (Usaha Mikro, Kecil, dan Menengah) merupakan usaha yang dimiliki oleh perorangan, kelompok, maupun badan usaha yang telah memenuhi syarat atau ketentuan sebagai usaha mikro. Berdasarkan data yang dimiliki oleh salah satu wilayah di Provinsi Jambi, yaitu Kota Jambi pada tahun 2016 terdapat 8.081 pelaku UMKM seperti yang dipubliksaikan melalui melalui situs kota Jambi (Jambikota, 2021). Namun berdasarkan data UMKM yang dipublikasikan melalui situs berita Jambi (Rahmatia, 2021), bahwa data UMKM pada tahun 2019 sebanyak 1.073 dan meningkat pada tahun 2020 menjadi 3.513.

Pada kegiatan pengabdian kepada masyarakat (PKM) yang kami lakukan di Jambi melibatkan pelaku UMKM sebanyak 92 UMKM yang dibagi menjadi enam kelompok dalam pelaksanaannya. Kami Kelompok B6 sebagai bagian dari Tim PKM melakukan kegiatan 
pengabdian yang diikuti oleh 12 pelaku UMKM terdiri dari UMKM Menjahit, Gorengan Dua Putra, Toko Sikembar, Angkringan Na'e, Warung Lontong, Minuman Sehat Jambi, Cucian Karpet Hitam, Azwar, Barokah Ina, Ibu Najwa, Madu Hutan, dan Kerajinan Tas Kecambang dan Kesenian.

\section{Permasalahan mitra}

Masalah paling utama yang dihadapi para pelaku UMKM merupakan masalah yang klasik, yaitu permasalahan minimnya modal usaha yang dimiliki dan mengalami kesulitan untuk mendapatkan modal tambahan. Permasalahan ini menyebabkan pelaku UMKM tidak dapat menciptakan inovasi baru terhadap produknya, dan tidak mampu meningkatkan jumlah produk yang dihasilkan untuk memperoleh keuntungan yang lebih banyak. Masalah berikutnya adalah mengenai kesulitan melakukan pendistribusian produk UMKM yang dikelolanya karena kurangnya relasi dalam pengembangan pendistribusian. Para pelaku UMKM rata-rata melakukan pendistribusian produknya hanya kepada para mitra atau perorangan yang dikenalnya sehingga jangkauannya tidak luas. Permasalahan terbaru yang dirasakan oleh pelaku UMKM adalah tentang penggunaan media online sebagai sarana promosi dan penjualan produknya. Sehingga untuk memperluas pendistribusian barang semakin sulit apabila tidak memanfaatkan media online untuk pemasarannya. Pada kegiatan PKM ini, kami memfokuskan pada pemberian pengetahuan tentang pemanfaatan media online sebagai sarana promosi dan penjualan, yaitu melalui media sosial, layanan pesan antar, marketplace, dan online store. Hasil dari PKM ini diharapkan para pelaku UMKM fokus pada suatu saluran pemasaran secara online yang tepat.

\section{METODE PELAKSANAAN}

\section{Metode}

Metode yang digunakan untuk tercapainya tujuan pengabdian kepada masyarakat ini adalah dengan mengadakan seminar, sosialisasi tentang petingnya ecommerce, dan diskusi dalam menerapkan ecommerce. Tahapan pelaksanaan PKM dimulai dari identifikasi mitra, pedampingan penyusunan proses bisnis yang dilakukan oleh tim PKM lainnya, pertemuan dengan mitra. Pertemuan dilakukan melalui aplikasi Zoom, yaitu aplikasi komunikasi yang menggunakan audio, video, dan sarana presentasi. Tahapan yang dilakukan dalam pemaparan dan diskusi antara lain: tujuan menyampaikan dasar pemikiran untuk para pelaku UMKM agar dapat beralih ke digital, memahami apa yang dimaksud dengan ecommerce (perdagangan secara elektronik, pemasaran dan transaksi secara elektronik). Penjelasan tentang apa yang dapat dilakukan oleh eommerce, automasi: menggantikan proses transaksi manual, integrasi: transaksi lebih efisien dan efektif, publikasi: promosi melalui media bersifat online, interaksi: antar penjualan dan pembeli secara digital, transaksi: media transaksi yang gunakan beragam.

\section{Partisipasi mitra}

Partisipasi mitra dalam pelaksanaan PKM adalah sebagai peserta dalam sosialisasi pemanfaatan media digital untuk pengembangan pemasaran dan penjualn secara online melalui layanan pesan antar, media sosial, market place, dan online shop (online store). Selain itu juga melakukan diskusi yang bersifat teknis tentang penggunaan media digital, diskusi terhadap kendala yang dihadapai dalam pemanfaatan media digital tersebut. Mitra memiliki partisipasi yang aktif untuk mendapatkan pemahaman yang benar tentang pemanfaatan media online sebagai sarana pemasaran produk UMKMnya.

\section{HASIL DAN PEMBAHASAN Pembahasan kegiatan PKM}


Pelaksanaan Kegiatan PKM untuk UMKM Jambi dilaksanakan melalui apliasi komunikasi Zoom. Berdasarkan diskusi pada beberapa UMKM, dapat diketahui sebagian UMKM di Jambi sudah ada yang menggunakan media online dalam menjalankan bisnis usahanya dengan tahap model ecommerce yang berbeda-beda. Ecommerce adalah kegiatan membeli atau menjual produk pada layanan online atau melalui internet. Perdagangan secara elektronik ini mengacu pada teknologi seperti perdagangan secara mobile, pemasaran melalui internet, proses transaksi secara online, pertukaran data secara elektronik, sistem pengelolaan inventori, dan sistem pengumpulan secara otomatis [Banda, 2019]. Terdapat empat jenis model ecommerce yang dapat menggambarkan hamper setiap transaksi yang terjadi antara konsumen dan pelanggan. Empat jenis ecommerce itu antara lain: bisnis ke konsumen (B2C), bisnis ke bisnis (B2B), konsumen ke konsumen $(\mathrm{C} 2 \mathrm{C})$, dan konsumen ke bisnis (C2B). Ecommerce bisa mengambil bentuk berbeda yang melibatkan hubungan transaksi yang berbeda antara bisnis ke konsumen, serta obyek yang dipertukarkan pada transaksinya. Website ecommerce $C 2 C$ mengusung model bisnis yang melibatkan transaksi antar konsumen. Kedua pihak tidak bertemu secara langsung, namun hanya lewat platform online pihak ketiga, sebagai contoh: Tokopedia dan Bukalapak.

\section{Hasil kegiatan PKM}

Berdasarkan pada pembahasan bersama dengan para pelaku UMKM, diketahui bahwa para pelaku UMKM sangat tertarik dalam memanfaatkan marketplace dan online store untuk memasarkan produk UMKMnya, namun demikian pembangunan fasilitas untuk online store belum memungkinkan bagi mereka karena sumberdaya yang belum dimiliki untuk mendukung online store. Penggunaan istilah lain tentang online store adalah online shop. Online shopping adalah aktivitas atau tindakan membeli produk atau jasa melalui internet, yaitu membeli secara online melalui situs web penjual, memilih sesuatu, dan mengatur pengirimannya. Pembeli membayar barang atau jasa secara online dengan kartu kredit atau debit atau pada saat pengiriman (MBN, 2021). Perdagangan secara online perlu preferensi konsumen untuk produk terhadap kesukaan suatu produk. Preferensi konsumen ini mengakibatkan UKMK menjadi lebih maju atau bahkan mundur. Jika konsumen pada umumnya menyukai suatu produk, produk tersebut dapat bertahan lama. Namun jika konsumen tidak menyukai suatu produk, itu bisa hilang dengan sangat cepat. Preferensi konsumen mengacu pada, "bagaimana pelanggan memilih barang dan jasa dalam kaitannya dengan faktor-faktor seperti selera, preferensi, dan pilihan individu. Faktor-faktor seperti pendapatan konsumen dan harga barang tidak mempengaruhi produk atau jasa yang disukai konsumen" (Sunitha, 2014).

Para pelaku UMKM juga sangat tertarik memanfaatkan marketplace sebagai sebuah platform jual beli antara penjual dan pembeli dalam melakukan transaksi penjualan dan pembelian produk atau jasa secara online melalui website. Hal inilah yang perlu dilakukan oleh pelaku UMKM untuk memanfaatkan marketplace karena masih gratis dengan pengguna yang sangat banyak, dapat dikelola sendiri dengan mudah, memiliki pasar yang lebih luas dan besar. Para pelaku UMKM telah mengenal dan mengetahui adanya marketplace di Indonesia, seperti Lazada, Bukalapak, Tokopedia, dan Sophee. Kegiatan pengabdian yang kami lakukan melalu seminar, dan diskusi tentang markerplace menghasilkan pemahaman para pelaku UMKM tentang pemanfaatan marketplace.

Pada gambar 1 berikut ini merupakan salah satu kegiatan sosialisasi dan pelaksanaan seminar tentang pemanfaatan sosial media, marketplace, dan online shop (online store) kepada para pelaku UMKM. Dari beberapa pelaku UMKM memang telah menggunakan facebook bisnis, instagram binsis untuk memasarkan produk UMKMnya, tetapi masih lebih banyak yang belum memanfaatkannya terutama penggunaan media sosial, dan marketplace. 


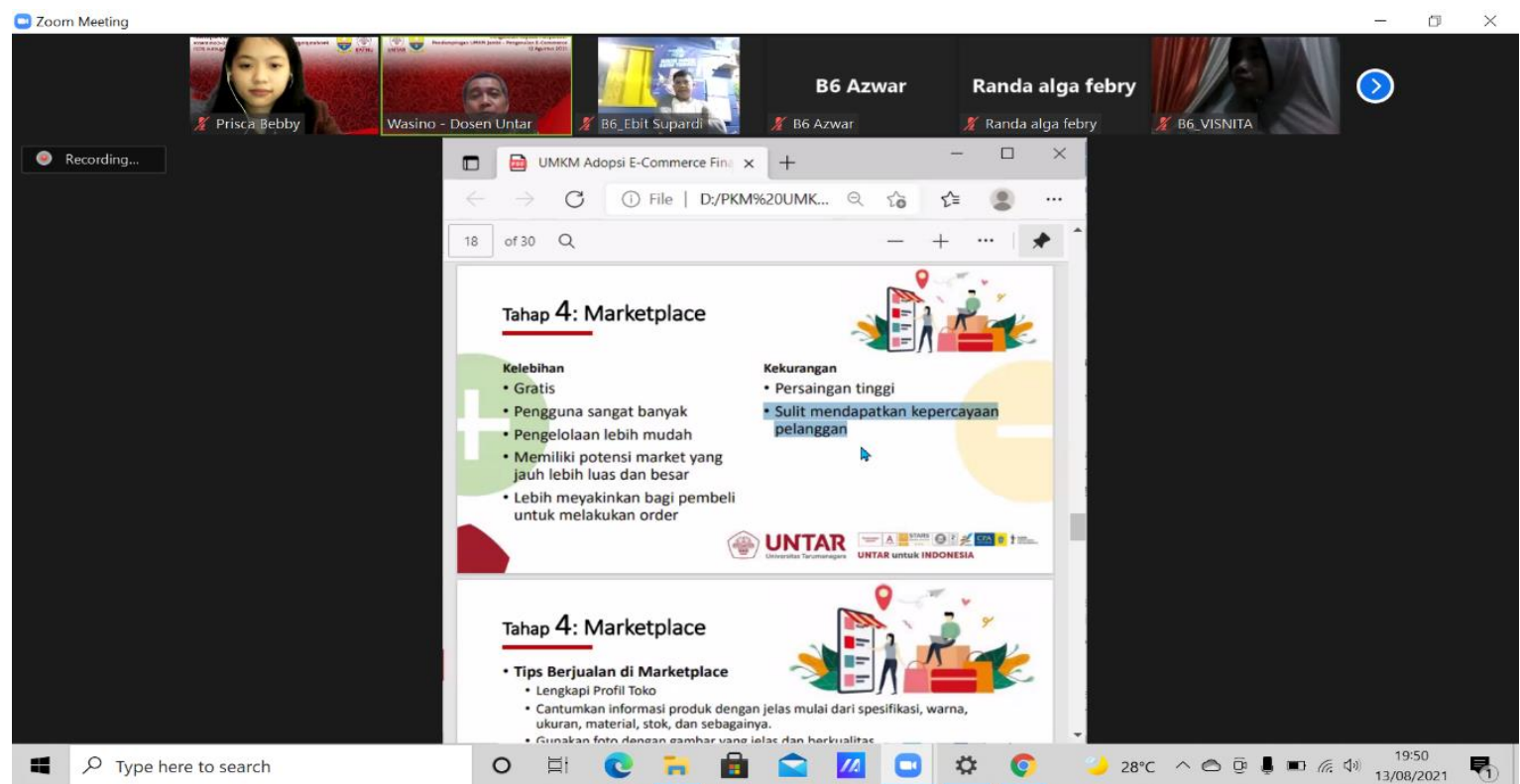

Gambar 1. Sosialisai dan seminar tentang ecommerce kepada UMKM

Marketplace dimanfaatkan oleh banyak pelaku bisnis kecil seperti UMKM, perusahaan menengah, dan perusahaan besar yang ada di Indonesia. Indonesia dan secara umum di wilayah Asia Tenggara memiliki lanskap yang kaya akan perusahaan ecommerce dengan merek yang diakui oleh sedikit orang di luar Asia Tenggara. Pemain terbesar, termasuk Shopee, Lazada dan Tokopedia, adalah pasar online yang menjual beragam barang, mirip dengan model Amazon. Mereka mengambil sebagian besar dari total penjualan ritel online Asia Tenggara, yang diperkirakan mencapai \$71 miliar pada tahun 2021. Shopee merupakan marketplace online terbesar di Asia Tenggara, dengan 343 juta kunjungan per bulan yang beroperasi di seluruh wilayah, dan belum lama ini diperluas ke Amerika Selatan. Indonesia yang merupakan ekonomi terbesar di Asia Tenggara, menyediakan 27\% trafik Shopee. Tabel 1 merupakan marketplace online terbesar di Asia Tenggara (Geldman, 2021).

Tabel 1 .Marketplace di Asia Tenggara

\begin{tabular}{cllll}
\hline No. & \multicolumn{1}{c}{ Nama } & \multicolumn{1}{c}{ Wilayah } & Kategori Produk & Kunjungan/Bulan \\
\hline 1 & Shopee & Southeast Asia & General & $342.8 \mathrm{M}$ \\
\hline 2 & Tokopedia & Indonesia & General & $137.3 \mathrm{M}$ \\
\hline 3 & Lazada & Southeast Asia & General & $128.4 \mathrm{M}$ \\
\hline 4 & Bukalapak & Indonesia & General & $30.4 \mathrm{M}$ \\
\hline 5 & Blibli & Indonesia & General & $20.6 \mathrm{M}$ \\
\hline 6 & Tiki & Vietnam & General & $15.6 \mathrm{M}$ \\
\hline 7 & Sendo & Vietnam & General & $7.4 \mathrm{M}$ \\
\hline 8 & Zalora & Southeast Asia & Fashion & $6.9 \mathrm{M}$ \\
\hline 9 & Qoo10 & Southeast Asia & General & $3.7 \mathrm{M}$ \\
\hline
\end{tabular}

Sumber: Webretailer

Selain memanfaatkan marketplace, pelaku UMKM juga perlu memanfaatkan media sosial sebagai sarana promosi produk UMKMnya untuk mendukung penjualan melalui marketplace. Para pelaku UMKM telah banyak yang memanfaatkan media sosial seperti Facebook (Facebook 
Ads), dan Instagram (Instagram Ads). Sosial media ini dimanfaatkan untuk melakukan promosi secara online yang memungkinkan antara pelaku UMKM saling berinteraksi dengan konsumen tanpa dibatasi ruang dan waktu. Gambar 2 berikut ini merupakan pelaksanaan diskusi tentang pemanfaatan sosial media sebagai sarana promosi produk UMKM.

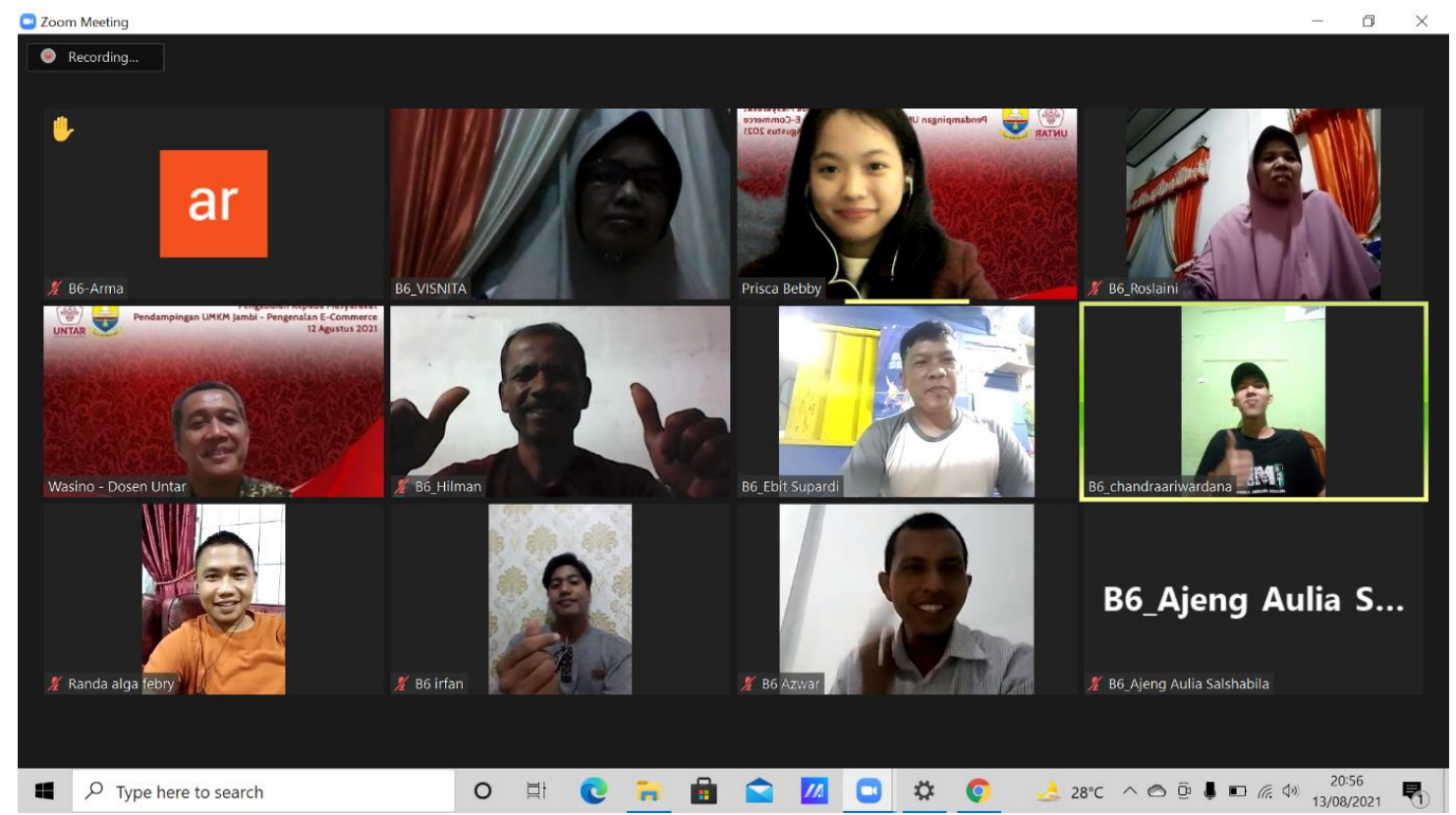

Gambar 2. Diskusi tentang pemanfaatan media sosial sebagai sarana promosi

Media sosial adalah istilah yang sering digunakan untuk merujuk pada bentuk media baru yang melibatkan partisipasi interaktif. Semua media sosial melibatkan platform digital, apakah itu seluler atau stasioner. Ada dua karakteristik umum untuk mendefinisikan media sosial. Pertama, media sosial memungkinkan adanya beberapa bentuk partisipasi. Media sosial adalah tidak pernah sepenuhnya bersifat pasif, meskipun terkadang situs jejaring sosial seperti Facebook mungkin terlihat pasif dari apa yang orang lain posting. Kedua, dan sejalan dengan sifatnya yang partisipatif, media sosial melibatkan interaksi. Interaksi ini dapat bersama teman, keluarga, atau kenalan yang sudah mapan atau dengan orang baru yang memiliki kesamaan minat atau bahkan lingkaran kenalan yang sama (Manning, 2014).

Salah satu UMKM yang dikelola oleh Bapak Chandra yaitu bisnis minuman bernama Susukua (Susu Kurma Madu) di Kota Jambi. Dalam menjalankan bisnis tersebut Bapak Chandra sudah memanfaatkan ecommerce dengan baik, karena untuk menjual dan pemasaran produknya selain pada outlet juga sudah menggunakan media online seperti Grab, Gofood, Shoppe, media sosial (Facebook Bisnis, Instagram Bisnis) dan sudah coba masuk ke dalam marketplace, dan Pak Chandra juga memiliki strategi untuk tetap meningkatkan penjualan produknya di masa pandemi ini seperti melakukan sistem promosi Susukua dapat menaikan imun tubuh sehingga strategi penjualan dan promosi yang baik dapat memberikan peluang untuk meningkatkan penjualan.

\section{KESIMPULAN}

Berdasarkan pemaparan materi yang disampaikan kepada para pelaku UMKM mengenai pentingnya ecommerce (perdagangan secara elektronik) dan melalui diskusi yang berlangsung dengan 12 UMKM dapat disimpulkan bahwa semua pelaku UMKM telah memanfaatkan media atau aplikasi whatsapp (yaitu aplikasi yang menyediakan layanan bertukar pesan dan panggilan yang sederhana) untuk menawarkan produk yang dijualnya. Terdapat satu UMKM yang telah memanfaatkan layanan media sosial untuk bisnis yaitu penggunaan instagram dan Facebook 
bisnis dan juga telah menggunaka layanan marketplace. Para pelaku UMKM memerlukan pendampingan dalam melakukan perdagangan secara elektronik dan perlu dukungan jaringan internet yang stabil di daerahnya.

\section{Ucapan Terima Kasih}

Ucapan terima kasih kami sampaikan kepada Lembaga Pengabdian Pada Masyarakat (LPPM) Universitas Tarumanagara (Untar) yang telah memberikan fasilitasi untuk melakukan pengabdian dengan memberikan seminar dan sosialisasi mengenai pemanfaatan media sosial dan marketplace kepada para pelaku UMKM di Jambi. Terima kasih juga kami sampaikan kepada Saudari Prisca Bebby Triola Angela Mulyono (825180038), mahasiswa Program Studi Sistem Informasi Untar yang membantu sebagai asisten pelaksana pengabdian kepada masyarakat (PKM).

\section{REFERENSI}

Banda, N. (2019). Ecommerce. Universidad Nacional de Itapúa.

Geldman, A. (2021). Online Marketplaces in Southeast Asia: A Unique Region for Ecommerce. Diakses tanggal 24 Agustus 2021 dari laman https://www.webretailer.com/.

Jambikota. (2018). Data UMKM. Diakses pada tanggal 15 Agustus 2021 dari laman http://data.jambikota.go.id/dataset/data-ukm/resource.

Manning, J. (2014). Definition and Classes of Social Media. University of Nevada, Reno.

MBN. (2021). Online shopping - definition and meaning. Market Business News. Diakses tanggal 20 Agustus 2021 dari laman https://marketbusinessnews.com/financialglossary/online-shopping-definition-meaning/

Rahmatia. (2021). Jumlah UMKM Meningkat, Rahmatia : Akan Kita Data Ulang. Diakses pada tanggal 15 Agustus 2021 dari laman https://jamberita.com/read/2021/02/01/5965334/

Sunitha, C.K, Gnanadhas, E. (2014). Online Shopping - An Overview. Holy Cross College. 